\title{
Lower to Mid-Pliocene pollen data from East African hominid sites, a review
}

\author{
Raymonde Bonnefille \\ Honorary Director of Research, CNRS, CEREGE, Aix Marseille University, \\ CNRS, IRD, INRAE, Coll. France, Technopole Arbois-Méditerranée, Aix en \\ Provence, France \\ Benjamin Bourel \\ CEREGE, Aix Marseille University, CNRS, IRD, INRAE, Coll. France, \\ Technopole Arbois-Méditerranée, Aix en Provence, France
}

\begin{abstract}
This paper presents fossil pollen data (39 samples) available for the Lower Pliocene outcrops at five hominid sites in East Africa located within the intertropical region between $3^{\circ}$ South to $11^{\circ}$ North. They are dated from 4.2 to 2.95 millions years (Ma). Most of these data were obtained many years ago, except one additional pollen assemblage recently obtained in the Woranso-Mille area of the Lower Awash valley, Ethiopia. In East Africa, Plio-Pleistocene sedimentary sequences are internationally renowned for the continuous palaeo-anthropological researches pursued for decades, following the discoveries of preserved remains of fossil hominins associated to a rich, diversified and abundant mammalian fauna. As a result of these new discoveries, geological studies have continued, being connected to following field expeditions and exploration of new sites in the Ethiopian Rift. We present here the revised geological context, adding chronological precision to previous age constraints of the original pollen data. For each terrestrial Pliocene site, we also include some comments regarding the significance of pollen counts and briefly discuss their interpretation for reconstructing past vegetation, environment, and inferred climatic parameters at the studied hominin sites.
\end{abstract}

\subsection{INTRODUCTION}

Pollen data provide information dealing with plant biodiversity and composition of past vegetation. Together with other palaeoecological proxies, these results concern regional environmental conditions, habitats, and food resources. All items are abundantly discussed to explain hominin species niches and evolution. Pollen studies from outcrops at hominin sites - that will be presented hereafter, and from deep core sediments off eastern Africa (e.g. Feakins et al. 2013) stand as critical contribution to the knowledge of hominin palaeoenvironments. Pollen data presented here mostly concern (with one exception) Pliocene outcrops from northern Ethiopia and Tanzania investigated a few decades ago.

Since the first publications of the original pollen data (Bonnefille 2010; Bonnefille and Riollet 1987; Bonnefille et al. 1987), new dated tephra (or tuffs) have been identified in the same outcrops (Table 1) and progress in the ${ }^{40} \mathrm{Ar} /{ }^{39} \mathrm{Ar}$ dating method have been made, notably for 
Table 1. List of dated tuffs from the Pliocene Hadar Formation (Ethiopia) used to calculate interpolated age of Hadar pollen samples (Campisano 2007).

\begin{tabular}{llll}
\hline Tuff and basalts & Abbreviation & Age $(\mathrm{Ma})$ & Original references \\
\hline Bouroukie Tuff 2U & BKT-2U & $2.96 \pm 0.006$ & Campisano 2007 \\
Bouroukie Tuff 2L & BKT-2L & $2.96 \pm 0.02$ & Semaw et al. 1997 \\
Kada Hadar Tuff & KHT & $3.20 \pm 0.01$ & Walter, 1994 \\
Triple Tuff 4 & TT-4 & $3.256 \pm$ & Campisano 2007 \\
Kada Damum Basalt & KMB & $3.30 \pm 0.04$ & Renne et al. 1993 \\
Kada Me'e Tuff & KMT & $3.36 \pm 0.002$ & Campisano 2007 \\
Sidi Hakoma Tuff & SHT & $3.42 \pm 0.03$ & Walter and Aronson 1993 \\
\hline
\end{tabular}

sites located in the Lower Awash Valley. Allowing previous stratigraphic placement of the pollen samples initially positioned versus tephra layers used as marker beds, it is now possible to revise ages of the pollen assemblages and place them in a more accurate chronological framework.

In this paper, we present the updated pollen data as supplementary data available for further research and interpretation (Supporting Online Material [SOM] Tables S1 to S4). We discuss them according to geographical location and chronological order. However, while addressing past vegetation changes through time it is necessary to consider the present and past altitudinal location at each site. Indeed, under the same global climatic conditions, past vegetation can differ between sites at different geographic locations. It is well known that relief modifies local climatic conditions. Altitudinal distribution of the vegetation inside zones (or belts) influences diversity in habitat patterns (Friis et al. 2010). A key feature of tectonic activity is the disruption of the river drainage. Geomorphological processes maintain habitats with variable topography through time (Reynolds et al. 2011). However, establishing past elevation at each fossil site for different time periods during the Lower Pliocene remains difficult. In this paper it is accepted that Ethiopian rifting and architecture of the Omo-Turkana basin was already attained since the eruption of the Gombe Group Basalt dated at c. 4.2 Ma (Erbello and Kidane 2018).

\subsection{PRELIMINARY REMARKS FOR FURTHER USE OF POLLEN DATA}

Pollen analysis of Plio-Pleistocene deposits from East Africa started in the 1970's with the first discoveries and field exploration in the search of hominin fossil remains documenting our ancestral origin. These initial pollen studies were strongly linked to the pioneer original stratigraphic, geological descriptions and mapping of the sedimentary terrestrial outcrops that yielded these remains. The universal and standardized framework, adopted at that time for collecting faunal remains and pollen samples at Laetoli, and at Hadar (Figure 1), was shared by all scientists involved, and still stands valid. Therefore, each pollen sample was given a label starting with the number corresponding to the fossil fauna locality, including hominin localities such as Afar Locality 333 (AL 333). Pollen sampling done along a section follows with underscore letters (a, $\mathrm{b}, \mathrm{c}$, etc.) indicating the stratigraphic succession.

Progress in absolute dating techniques provided further precision to date the fossil hominins remains, the abundant associated fauna and, therefore, pollen data. The initial stratigraphic position of pollen samples can now be integrated into the new geological studies recently carried out at each of the different sites (Campisano 2007; Campisano and Feibel 2008a, 2008b; Deino 2011; Harrison 2011). At the time of collecting pollen samples (except for sample MRD-210), GPS was not available, therefore approximate coordinates for the Hadar samples had to be 


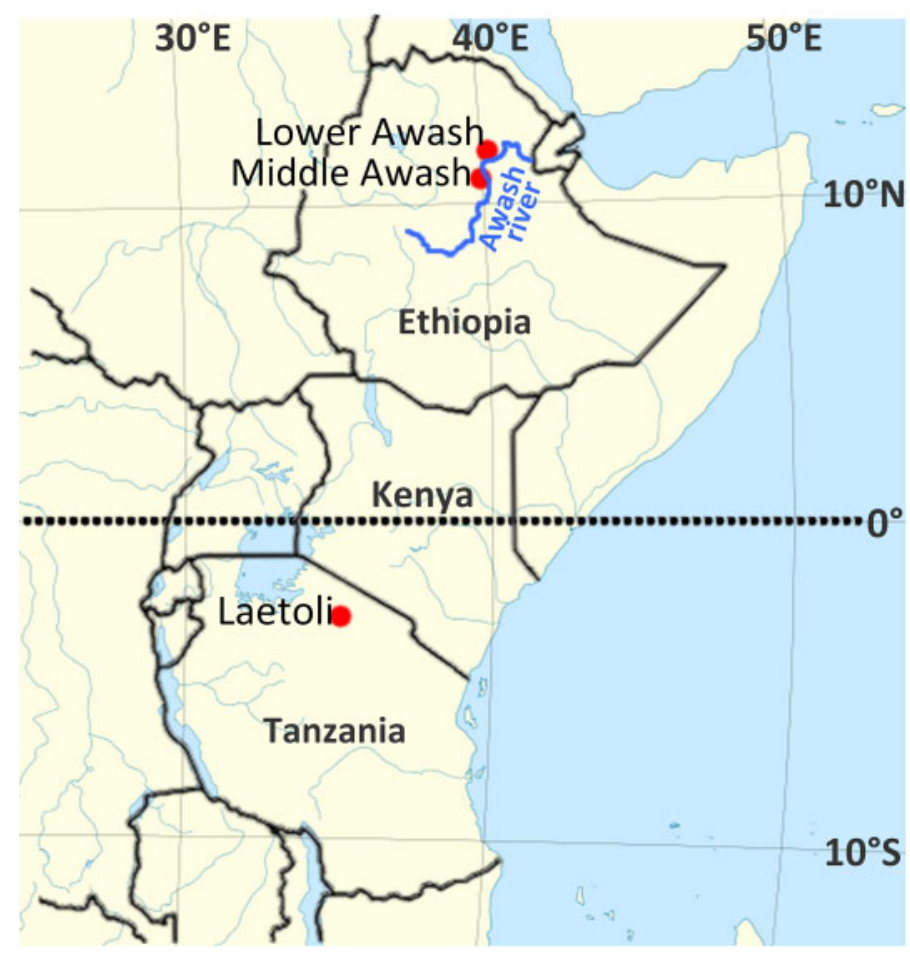

Figure 1. Location map of the Pliocene sites in Tanzania and Ethiopia (Middle and Lower Awash).

calculated by importing the initial map previously established on aerial photographs (Bonnefille et al. 1987) into a Geographic Information System (QGIS v3.2.2) (Table 2).

In the early days of pioneer African palynology, fossil pollen studies at Olduvai, Laetoli and Hadar were also associated to preliminary investigation of modern pollen soil samples from various vegetation types and plant collecting in vegetation surrounding the Pliocene sites. Interpretation of pollen data in term of past vegetation changes through time should also consider additional information of the setting in which these data were obtained. Indeed, different environmental contexts such as the occurrences of small or big lakes, existing delta or meandering river and floodplains, locally modify the pattern of the regional vegetation reflected by the composition and percentages of pollen taxa in the assemblages (spectra).

In this paper, sedimentary conditions provided by detailed and new geological studies are briefly summarized while comparing the chronological succession of the pollen data between the different terrestrial sites. Pliocene East African pollen sites are located at various elevations, even in the African Rift. Researchers who will address the vegetation dynamic through time, such as comparing with isotopic studies, have to remember that composition of modern and past vegetation vary according to local climatic patterns, relief and occurrence of water bodies. Moreover, East Africa is an area of tectonic changes and active volcanism. But palaeo-topography and palaeo-geography are far from being established at sites older than $3 \mathrm{Ma}$.

Pollen data included in this paper inform on terrestrial past vegetation for snapshot windows through the Pliocene. Considering their accurate dating they can be considered as valuable benchmark in the expectation of continuous pollen record from terrestrial cores. Although thoroughly investigated, Pliocene outcrops of tropical East Africa, hardly preserved fossil pollen. 
Table 2. List of Pliocene pollen samples from the Lower Awash, Ethiopia. Nb 0 (Bonnefille et al. 1987; Saylor et al. 2019), N (Bonnefille et al. 2004).

\begin{tabular}{|c|c|c|c|c|c|c|c|}
\hline Nb 0 & $\mathbf{N}$ & Stratigraphic position & Locality & $\begin{array}{c}\text { Geographical } \\
\text { coordinates }\end{array}$ & Collector & Submember & Age (Ma) \\
\hline $55 \mathrm{Nj}$ & (13) & Clay $2 \mathrm{~m}$ below tuff BKT-2 & Hadar, Kada Hadar & $11^{\circ} 08^{\prime} 31^{\prime \prime N} ; 40^{\circ} 34^{\prime} 49^{\prime \prime} \mathrm{E}$ & $\mathrm{RB}, \mathrm{AV}$ & KH-2 & 2.95 \\
\hline $116 f$ & (12) & Clay $10 \mathrm{~m}$ above tuff complex TT- 4 & Hadar, Kada Hadar & $11^{\circ} 08^{\prime} 25^{\prime \prime} \mathrm{N} ; 40^{\circ} 35^{\prime} 34^{\prime \prime} \mathrm{E}$ & RB 1973 & DD-1/DD-2 & 3.22 \\
\hline $116 \mathrm{e}$ & (11) & Silt $2 \mathrm{~m}$ above tuff complex TT -4 & Hadar, Kada Hadar & $11^{\circ} 08^{\prime} 25^{\prime \prime} \mathrm{N} ; 40^{\circ} 35^{\prime} 34^{\prime \prime} \mathrm{E}$ & RB 1973 & DD-1 & 3.23 \\
\hline $333 d$ & $(10)$ & Clay Ostracod layer in tuff complex TT- 4 & Hadar, Baruteita & $11^{\circ} 07^{\prime} 39^{\prime \prime} \mathrm{N} ; 40^{\circ} 34^{\prime} 38^{\prime \prime} \mathrm{E}$ & $\mathrm{RB}, \mathrm{AV}$ & SH-4/DD-1 & $3.256 \pm 0.018$ \\
\hline $333 \mathrm{c}$ & (9) & Black clay, $50 \mathrm{~cm}$ below ostracod layer & Hadar, Baruteita & $11^{\circ} 07^{\prime} 39^{\prime \prime} \mathrm{N} ; 40^{\circ} 34^{\prime} 38^{\prime \prime} \mathrm{E}$ & $\mathrm{RB}, \mathrm{AV}$ & SH-4 & 3.24 \\
\hline $333 b$ & (8) & $\begin{array}{l}\text { Sandy clay below tuff complex TT- } 4 \text { and Pink } \\
\text { Marl }\end{array}$ & Hadar, Baruteita & $11^{\circ} 07^{\prime} 39^{\prime \prime} \mathrm{N} ; 40^{\circ} 34^{\prime} 38^{\prime \prime} \mathrm{E}$ & $\mathrm{RB}, \mathrm{AV}$ & SH-4 & 3.25 \\
\hline $134 \mathrm{~b}$ & (7) & Green clay $20 \mathrm{~cm}$ below Tuff complex TT- 4 & Hadar & $11^{\circ} 07^{\prime} 45^{\prime \prime} \mathrm{N} ; 40^{\circ} 35^{\prime} 53^{\prime \prime} \mathrm{E}$ & RB 1974 & SH-4 & 3.25 \\
\hline $266 \mathrm{~b}$ & (6) & Green clay below tuff complex TT- 4 & Hadar, Kada Hadar & $11^{\circ} 07^{\prime} 40^{\prime \prime} \mathrm{N} ; 40^{\circ} 35^{\prime} 44^{\prime \prime} \mathrm{E}$ & RB 1974 & SH-4 & 3.25 \\
\hline $228 \mathrm{~b}$ & (5) & Silt lower contact of pink marl & Hadar, Sidi Hakoma & $11^{\circ} 06^{\prime} 19^{\prime \prime} \mathrm{N} ; 40^{\circ} 34^{\prime} 35^{\prime \prime} \mathrm{E}$ & RB 1974 & $\mathrm{SH}-3 / \mathrm{SH}-4$ & 3.28 \\
\hline $228 \mathrm{a}$ & (4) & Brown clay gastropod, $11 \mathrm{~m}$ above $\mathrm{SH}-3 \mathrm{~s}$ & Hadar, Sidi Hakoma & $11^{\circ} 06^{\prime} 19^{\prime \prime} \mathrm{N} ; 40^{\circ} 34^{\prime} 35^{\prime \prime} \mathrm{E}$ & RB 1974 & SH-3 & 3.30 \\
\hline $280 \mathrm{Nj}$ & (3) & Silty clay $3 \mathrm{~m}$ above top $\mathrm{SH}-3 \mathrm{~s}$ & Hadar Kada Hadar & $11^{\circ} 07^{\prime} 15^{\prime \prime} \mathrm{N} ; 40^{\circ} 37^{\prime} 53^{\prime \prime} \mathrm{E}$ & RB 1974 & SH-3 & 3.30 \\
\hline $\mathrm{KMm}$ & (2) & Clay with plant debris, gasteropods & Hurda & $11^{\circ} 06^{\prime} 36^{\prime \prime} \mathrm{N} ; 40^{\circ} 39^{\prime} 03^{\prime \prime} \mathrm{E}$ & $\mathrm{RB}, \mathrm{AV}$ & SH-2 & 3.35 \\
\hline KM12 & (2) & Silty sand with plant remains & Hurda & $11^{\circ} 06^{\prime} 36^{\prime \prime} \mathrm{N} ; 40^{\circ} 39^{\prime} 03^{\prime \prime} \mathrm{E}$ & $\mathrm{RB}, \mathrm{AV}$ & SH-2 & 3.35 \\
\hline KMl1 & (2) & Silty sand with plant remains & Hurda & $11^{\circ} 06^{\prime} 36^{\prime \prime} \mathrm{N} ; 40^{\circ} 39^{\prime} 03^{\prime \prime} \mathrm{E}$ & $\mathrm{RB}, \mathrm{AV}$ & SH-2 & 3.36 \\
\hline KMk & (2) & Laminated clay with intercalated tuff & Hurda & $11^{\circ} 06^{\prime} 36^{\prime \prime} \mathrm{N} ; 40^{\circ} 39^{\prime} 03^{\prime \prime} \mathrm{E}$ & $\mathrm{RB}, \mathrm{AV}$ & SH-2 & 3.36 \\
\hline $\mathrm{KMj}$ & (2) & Laminated clay & Hurda & $11^{\circ} 06^{\prime} 36^{\prime \prime} \mathrm{N} ; 40^{\circ} 39^{\prime} 03^{\prime \prime} \mathrm{E}$ & $\mathrm{RB}, \mathrm{AV}$ & SH-2 & 3.37 \\
\hline $\mathrm{KMi}$ & (2) & Grey clay with gastropods & Hurda & $11^{\circ} 06^{\prime} 36^{\prime \prime} \mathrm{N} ; 40^{\circ} 39^{\prime} 03^{\prime \prime} \mathrm{E}$ & $\mathrm{RB}, \mathrm{AV}$ & SH-2 & 3.37 \\
\hline $\mathrm{KMh}$ & (2) & Ostracods clay with gastropods $10 \mathrm{~m}$ above SHT & Hurda & $11^{\circ} 06^{\prime} 36^{\prime \prime} \mathrm{N} ; 40^{\circ} 39^{\prime} 03^{\prime \prime} \mathrm{E}$ & $\mathrm{RB}, \mathrm{AV}$ & SH-2 & 3.37 \\
\hline $\mathrm{KMg}$ & (2) & Silty sand $2 \mathrm{~m}$ above lignite layer & Hurda & $11^{\circ} 06^{\prime} 36^{\prime \prime} \mathrm{N} ; 40^{\circ} 39^{\prime} 03^{\prime \prime} \mathrm{E}$ & $\mathrm{RB}, \mathrm{AV}$ & SH-2 & 3.37 \\
\hline KMf & (2) & $\begin{array}{l}\text { Clay gastropods and ostracods above lignite } \\
\text { layer }\end{array}$ & Hurda & $11^{\circ} 06^{\prime} 36^{\prime \prime} \mathrm{N} ; 40^{\circ} 39^{\prime} 03^{\prime \prime} \mathrm{E}$ & $\mathrm{RB}, \mathrm{AV}$ & SH-2 & 3.37 \\
\hline $\mathrm{KMe}$ & (2) & Lignite thick layer within KMT & Hurda & $11^{\circ} 06^{\prime} 36^{\prime \prime} \mathrm{N} ; 40^{\circ} 39^{\prime} 03^{\prime \prime} \mathrm{E}$ & $\mathrm{RB}, \mathrm{AV}$ & SH-2 & $3.36 \pm 0.02$ \\
\hline $\mathrm{KMd} 2 \mathrm{~b}$ & (2) & Clay with gastropods, fishes below lignite layer & Hurda & $11^{\circ} 06^{\prime} 36^{\prime \prime} \mathrm{N} 40^{\circ} 39^{\prime} 03^{\prime \prime} \mathrm{E}$ & $\mathrm{RB}, \mathrm{AV}$ & SH-2 & 3.37 \\
\hline $\mathrm{KMd} 2 \mathrm{a}$ & (2) & Clay with gastropods, fishes below lignite layer & Hadar, Hurda & $11^{\circ} 06^{\prime} 36^{\prime \prime} \mathrm{N} ; 40^{\circ} 39^{\prime} 03^{\prime \prime} \mathrm{E}$ & $\mathrm{RB}, \mathrm{AV}$ & SH-2 & 3.37 \\
\hline KMc & (2) & Silty clay $2.5 \mathrm{~m}$ above sample b & Hurda & $11^{\circ} 06^{\prime} 36^{\prime \prime} \mathrm{N} ; 40^{\circ} 39^{\prime} 03^{\prime \prime} \mathrm{E}$ & $\mathrm{RB}, \mathrm{AV}$ & SH-2 & 3.37 \\
\hline $\mathrm{KMb}$ & (2) & Brown silt $1 \mathrm{~m}$ above sample a & Hurda & $11^{\circ} 06^{\prime} 36^{\prime \prime} \mathrm{N} ; 40^{\circ} 39^{\prime} 03^{\prime \prime} \mathrm{E}$ & $\mathrm{RB}, \mathrm{AV}$ & SH-2 & 3.38 \\
\hline KMa & (2) & Black clay $26 \mathrm{~m}$ above SHT & Hurda & $11^{\circ} 06^{\prime} 36^{\prime \prime} \mathrm{N} ; 40^{\circ} 39^{\prime} 03^{\prime \prime} \mathrm{E}$ & $\mathrm{RB}, \mathrm{AV}$ & $\mathrm{SH}-2$ & 3.38 \\
\hline $398 b$ & (1) & Green clay interbedded between two SHT layers & Dikika Oudaleita & $11^{\circ} 06^{\prime} 12^{\prime \prime} \mathrm{N} ; 40^{\circ} 36^{\prime} 39^{\prime \prime} \mathrm{E}$ & RB 1974 & $\mathrm{BM}$ & 3.42 \\
\hline MRD-210 & & Deltaic sands, below Mille Tuff & Worenso MRD-VP-1 & $11^{\circ} 32^{\prime} 55^{\prime \prime} \mathrm{N} ; 40^{\circ} 28^{\prime} 01 " \mathrm{E}$ & Levin 2018 & BM & 3.80 \\
\hline Meshellu & & "Lignite/coal" $20 \mathrm{~cm}$ thick above green clay & Dikika Meshellu River & $11^{\circ} 05^{\prime} 00^{\prime \prime} \mathrm{N} ; 40^{\circ} 40^{\prime} 37^{\prime \prime} \mathrm{E}$ & RB, JK 1973 & $\mathrm{BM}$ & 4.00 \\
\hline
\end{tabular}

Among the whole set of sediment samples collected from the different geological strata at the different sites, the degree of success in pollen extraction as result of preservation was $<10 \%$ of the total processed samples, despite preferentially selecting lacustrine deposits (Bonnefille et al. 1987). It is hoped that further investigation and pollen studies carried out on sediment obtained from deep terrestrial drilling projects, such as the Hominin Sites and Palaeolakes Drilling Project (Cohen et al. 2016) can provide additional results. Following this line, two cores (NAW14-1A, NAO14-1B) (Figure 2) collected from the assumed position of the Hadar palaeo-lake indicate that the core sediments cover the period between 2.91 Ma and 3.33 Ma (Campisano 2012; Campisano et al. 2017; Garello 2019). These sediments have provided nine additional pollen assemblages corresponding to Pliocene strata (Bourel 2020).

During the early days of development of tropical palynology, fossil pollen identifications were based upon many botanical papers dealing with plant systematics. Descriptions of pollen 


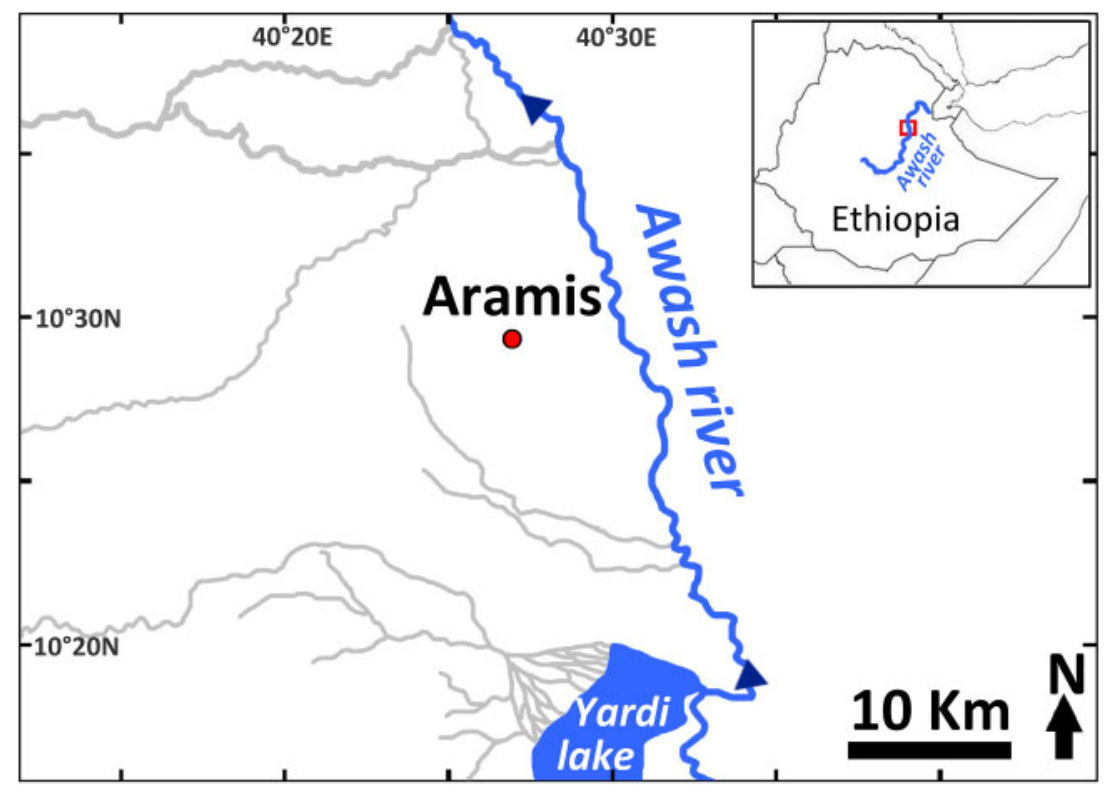

Figure 2. Location map of the lower Pliocene pollen samples from Aramis (dated 4.4 Ma) in the Middle Awash valley.

from modern plants of tropical Africa illustrated in several pollen atlases (Bonnefille 1971a, 1971b; Bonnefille and Riollet 1980) were the basis for fossil pollen identifications. It might also be noted that all pollen identifications and counting of the data presented herein were carried out in the same laboratory though its location and name have changed over the years (pre1979: Laboratoire de Géologie du Quaternaire (LGQ) CNRS Bellevue-Meudon; 1979-1994 LGQ, Marseille-Luminy University; post-1994: CEREGE, Aix-en-Provence). Researchers and technical staff used the same criteria and nomenclature for their pollen diagnoses and compared fossil pollen to analogues included in the same modern pollen reference collection $(n=7000$ species) built by the first author, and now stored at CEREGE. This fact points to the consistency and taxonomical homogeneity of the East African Pliocene pollen data provided in this paper. Considering that our pollen studies were initiated before isotopic methods had been developed, the reference collection is focused on tree species more than on herbaceous plants. The homogenous pollen morphology of all genera and species among gramineae does not allow distinction between $\mathrm{C}_{3}$ and $\mathrm{C}_{4}$ grasses.

From the phytogeographical point of view, the African Plio-Pleistocene sites discussed here are located within the intertropical region. This zone belongs to the phytogeographical domain 'Somalia-Masai Acacia-Commiphora steppe', mostly defined upon species endemism and homogenous ecological climatic conditions. It is named after the abundance of more than hundred trees species for each of these two very common genera (White 1983). This region is now also called and mapped as 'deciduous bushland and thicket' (van Breugel et al. 2015). The landscape of the 'Somalia-Masai Acacia-Commiphora deciduous bushland and thicket' does not appear homogenous since a great diversity of local ecosystems exists. The density of forest cover varies near rivers, lakes, springs, high water tables, and on mountains. On a broader regional scale, the density of tree and shrub cover within this landscape depends on the monsoon rainfall distribution at the different sites. Moreover, the Pliocene sites investigated in this paper are located between 500 and $1500 \mathrm{~m}$ asl. Therefore, temperature, amount of rainfall, and patterns of rainfall distribution vary accordingly to the topographic context of the Rift. 
Proximity of mountains and volcanoes allows various types of evergreen forests to be established on their slopes. Within the large Somalia-Masai region, the vegetation belts on different mountains have distinct floristic characteristics (such as different types of forests) and constitute an independent phytogeographical domain called 'Afromontane', with specific plant taxa (White 1983). Pliocene fossil pollen assemblages from fluviatile sediment collected in the lowlands may include pollen signal of different ecosystems mixed together. While reconstructing past vegetation around a studied site, spatial distribution of different ecosystems may be postulated using knowledge of the palaeogeographical and geological contexts, both at the local and regional scales. Such an approach relies on thorough studies of modern pollen deposition (taphonomy), and appropriate assumptions based upon geological studies.

\subsection{LOWER PLIOCENE DATA (4.4 TO 3.8 MA)}

Palaeobotanical data from this time period come from Ethiopia (four sites) and Tanzania (one site).

\subsubsection{Middle Awash Valley, Aramis locality, $565 \mathrm{~m}$ asl, $10^{\circ} 30^{\prime} \mathrm{N}, 40^{\circ} 30^{\prime} \mathrm{E}, 4.3 \mathrm{Ma}$, Ethiopia}

Extensive Pliocene floodplain deposits occur in the Middle Awash Valley of the Ethiopian Rift. At Aramis (Figure 2), field prospections provided fossil remains of Ardipithecus ramidus, an interesting hominin associated with an abundant fauna dated at 4.4 Ma (White et al. 2009). Pollen samples collected directly in the sediment that contained Ardipithecus ramidus did not provide consistent pollen results. We found a few grains of sedges (Cyperaceae), grasses and palm tree attributed to Hyphaene/Borassus. All these plants were later documented by abundant phytoliths found in the same dated sediment (Barboni et al. 2019; WoldeGabriel et al. 2009). Fossil wood studies identified trees such as Ficus (Jolly-Saad et al. 2010), Syzygium, Cordia and Rothmania (Jolly-Saad and Bonnefille 2012), together with Celtis, a tree identified by the abundant calcified stones of its fruits (WoldeGabriel et al. 2009). All these trees provide edible fruits. In agreement with the fossil fauna and preserved geological evidences (tufa) for groundwater discharge areas (springs), the palaeobotanical record is interpreted as a spring forest or palm woodland that allowed a forest habitat for this hominin adapted to climbing within a grass-dominated landscape (Barboni et al. 2019).

\subsubsection{Lower Awash valley, Meshellu/Dikika, $500 \mathrm{~m}$ asl, $1^{\circ}{ }^{\circ} 5^{\prime} \mathrm{N}, 40^{\circ} 41^{\prime} \mathrm{E}, 4-3.8 \mathrm{Ma}$, Ethiopia}

A pollen sample collected in 1973 by R. Bonnefille and J. Kalb from lacustrine organic sediment exposed along the Meschellu drainage, east of the Dikika area (Figure 3) has provided a pollen spectrum that documents a past vegetation that is fairly different from that of Aramis site (Bonnefille 2010, Table 1) (SOM Table S1). According to its stratigraphic position below the Sidi Hakoma Tuff (SHT), the pollen sample belongs to the Basal Member of the Hadar Formation. It is likely placed between the Ikini Tuff dated to $3.8 \mathrm{Ma}$ (Wynn et al. 2006) and the Afar Stratoid Series Basalt dated to $4 \mathrm{Ma}$ (Wynn et al. 2006). At Meshellu/Dikika, c. 4 Ma ago, a large extensive swamp with abundant aquatic Typha and sedges occurred among an herbaceous vegetation including herbs such as Isoglossa, Apiaceae, Brassicaceae, Caryophyllaceae, Gentianaceae, Polygonaceae, mostly abundant in current highland swamps or grasslands, such as observed by the first author in the Bale Mountains. All tree pollen taxa (Alchornea, Macaranga, Hagenia, Rubiaceae, Hymenodictyon, etc.) belong to highland humid forests in which the conifer Podocarpus is absent. This pollen assemblage is devoid of pollen taxa from dry evergreen bushland or 


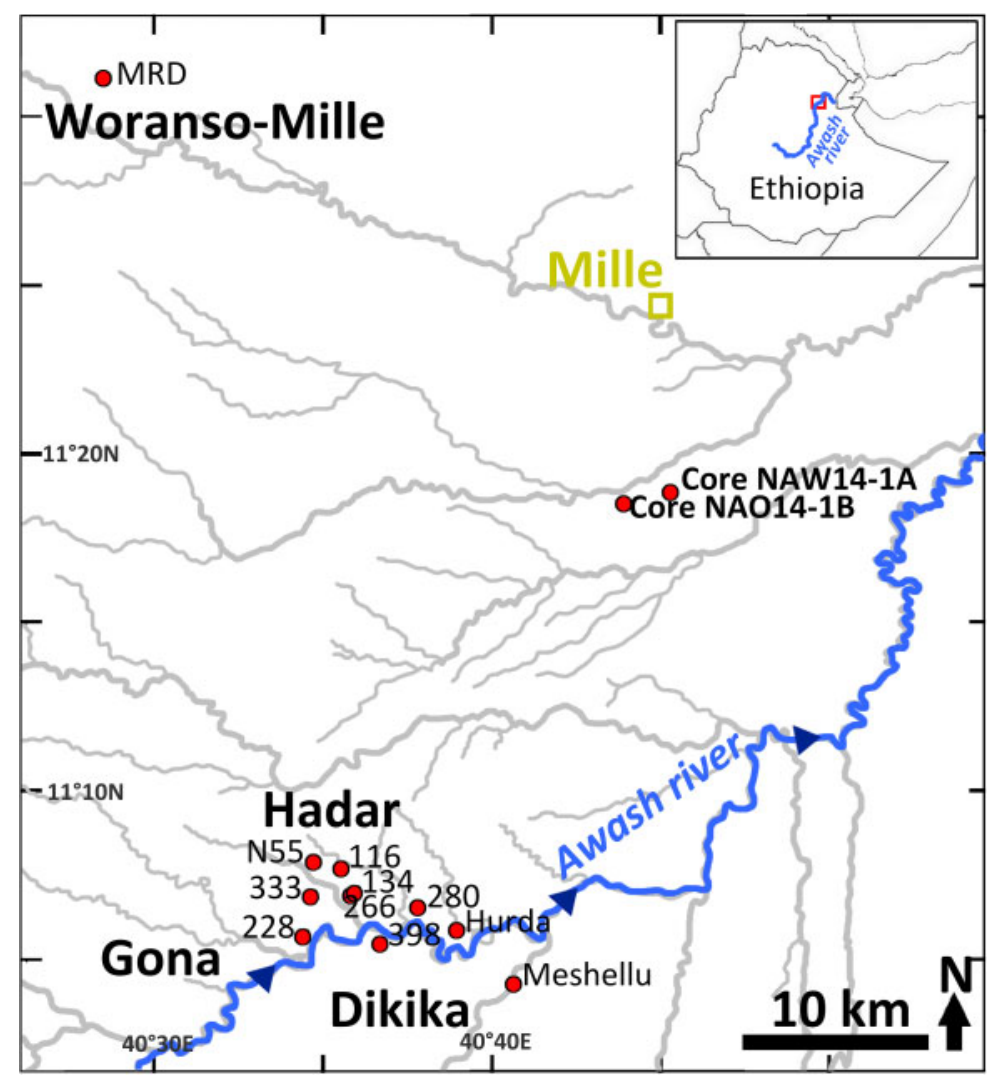

Figure 3. Location map of the Pliocene pollen samples from Woranso/ Mille (3.8 Ma), and Hadar site (3.4 to 2.9 Ma), in the Lower Awash valley.

sub-desert steppe which prevail in present dry climatic conditions of the Ethiopian Rift. Humid and cool local conditions explain the occurrence of an extended swamp among a diversified tropical forest with great affinities with high elevation humid forests and grasslands of the Ethiopian plateau today.

\subsubsection{Lower Awash Valley, Woranso-Mille, $660 \mathrm{~m}$ asl, $11^{\circ} 33^{\prime} \mathrm{N}, 4^{\circ} 28^{\prime} \mathrm{E}, 3.8 \mathrm{Ma}$, Ethiopia}

The MRD-210 pollen spectrum was recently extracted from a sandy horizon directly providing remains of Australopithecus anamensis dated 3.8 Ma (Figure 3) (Saylor et al. 2019) (SOM Table S2). Within the geological context of deltaic deposits, abundant pollen of the creeping herb Tribulus terrestris and Nyctaginaceae with the forb Aerva occupied the alternatively inundated floodplain such as found today in the Okavango Delta. Pollen of Acacia (a botanical genus now separated into Vachellia and Senegalia) is exceptionally abundant. The low pollen representation of this taxon in samples of modern vegetation, and its low dispersal ability (Hamilton 1982) indicate that dense Acacia woodland occurred locally. Including Euclea and Combretum, such woodland seems to have affinities with modern deciduous woodland encountered today on escarpments at $c$. 1300-1500 m asl. Boscia and Capparaceae together with Rhus, Acalypha and Trilepisium could also be found in riparian forest. Other tree pollen, such as Juniperus, 


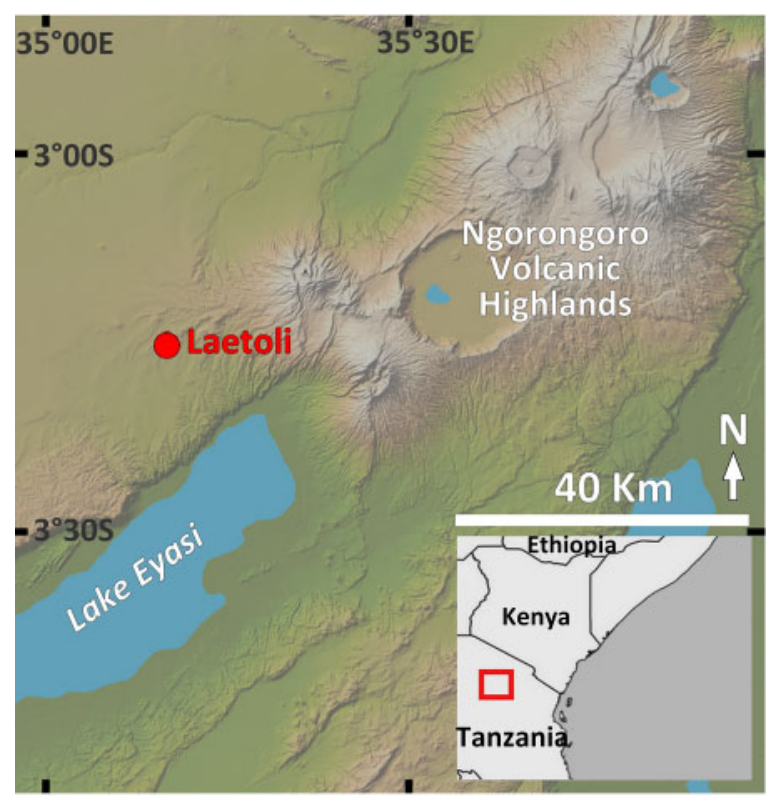

Figure 4. Topographic map showing the Laetoli location on the slopes of several volcanos around the Ngorongoro caldera, East African Rift (Tanzania).

Podocarpus, Olea and Hagenia attest to the occurrence of a drier conifer mountain forest, similar in composition to that present on Eastern Ethiopian highlands. Habitat scores based on plant functional types (PFTs) method are highest for steppe (25\%) and woodland (34\%) whereas riparian dry open Acacia woodland is documented, locally, in the palaeovegetation (Saylor et al. 2019).

\subsubsection{Laetoli site, $1800 \mathrm{~m}$ asl, $3^{\circ} 13^{\prime} \mathrm{S}, 3^{\circ} 13^{\prime} \mathrm{E}, 3.83-3.8 \mathrm{Ma}$, Tanzania}

In the southern part of the Eastern Rift Valley, the Laetoli site is located at much higher elevation (1800 $\mathrm{m}$ asl) than other Middle and Lower Pliocene deposits from the Awash Valley in Ethiopia (Figure 1). Deposits consist of air-fall tuffs provided by the repeated activity of Ngorongoro volcanic highlands with no evidence of permanent water system other than possibly localized springs, and river drainage, south of our sampling area.

Pollen preservation was very poor in most terrestrial samples $(n=40)$ collected in the volcanic fossil-rich deposits of the Upper Laetolil Beds yielding remains of Australopithecus afarensis, including tracks of its fossilized footprints (Leakey et al. 1987). The Upper Laetolil Beds revealed less productive than the other sites, a conclusion confirmed by further investigation (Rossouw and Scott 2011).

Fossilized termite mounds were so abundant that we decided to investigate their infill in order to obtain some information on past vegetation (Bonnefille and Riollet 1987). It is assumed that termites feeding upon local surrounding vegetation, the ventilation shaft must have been open to the air during the interval in which the termitary was occupied. The hives were sealed shortly after the demise of the colony. Atmospheric pollen trapped in the hives was preserved under anaerobic conditions and the termite structure buried and fossilized by the volcanic ash. Indeed, macroscopic observation during field collecting showed organic matter, vegetal fragment tissues 
and pollen preserved in the hive chamber infill. Under such taphonomic conditions, possible bias of these pollen assemblages can be expected. In order to test such hypothesis, modern soil samples were collected in different ecosystems of the regional vegetation along a $30 \mathrm{~km}$ altitudinal transect, together with plant species (appendix A in Leakey et al. 1987). Modern pollen assemblages from short and medium grasslands between 1500 to $1800 \mathrm{~m}$ asl are characterized by the dominance of pollen from herbaceous plants, pollen of grasses being less abundant than pollen of others herbs or forbs of the Asteraceae, Acanthaceae, Amaranthaceae, Fabaceae and Cyperaceae. Overgrazing and burning by pastoralists may have contributed to increasing forbs and ligneous plants typical of the current short or medium grasslands of Laetoli/Olduvai region. In modern pollen surface samples collected from the wooded grassland or woodland surrounding the Laetoli area today at 1700-1800 m elevation, tree pollen including Acacia, Euclea and other Sudano-Zambezian taxa account for $20 \%$ of the total counts (Bonnefille and Riollet 1987). A homogenous signal of c. $2 \%$ pollen from forests, now covering the slopes of the 20 to $30 \mathrm{~km}$ distant volcanoes correspond to aeolian pollen transport. In the fossil pollen data, the distribution of the various taxa appears consistent with that in modern soil samples, an argument bringing to the fore that past vegetation at the site can be reconstructed from fossil pollen extracted from termite mounts infill.

Altogether, pollen data at Laetoli consist of ten pollen assemblages sampling only the Upper Laetolil Beds between 3.83 to $3.68 \mathrm{Ma}$. The oldest nine pollen samples collected in a 4 metres stratigraphic interval around Tuff 1 (Hay 1987) span an interval of c. 6 ka before $3.83 \mathrm{Ma}$, on the basis of sedimentation rate (Deino 2011). In between, there is a time span of $150 \mathrm{ka}$ with no pollen information. The youngest pollen assemblage was obtained from a hive chamber collected $3 \mathrm{~m}$ below the footprint tuff (Tuff 7) dated 3.66 Ma (Deino 2011). It has an attributed age of $3.68 \mathrm{Ma}$ (youngest sample ML-81-7).

The Laetoli pollen data (SOM Table S3) total 4354 identified and counted pollen grains. We note an important number of pollen taxa from trees and shrubs (26), most of them being regular components of evergreen bushland and mountain forests. Some pollen taxa Boscia and Celtis being also identified as seeds and fruit stones, macro-botanical remains recovered from the top part of the Laetolil Beds at 3.66 Ma (Bamford 2011). It is likely that deciduous woodland occupied the peneplain between Eyasi and Olduvai divides from 3.8 to 3.6 Ma ago. Percentages of pollen from Afromontane forests are three to five times greater than today indicating that such forests were more extensive or closer to the site during the Mid-Pliocene. The Laetoli herbaceous palynoflora is also remarkable by a great number of pollen taxa (c. 54) that belong to tropical families such as Acanthaceae, Amaranthaceae, Euphorbiaceae, Zygophyllaceae, with many Asteraceae, Fabaceae and Solanaceae, etc. The fossil pollen composition points to rich and diversified low and medium grasslands, together with grass pollen being more abundant than in the pollen samples from modern vegetation, a conclusion in agreement with the record of several grass phytoliths (Rossouw and Scott 2011).

At Laetoli, the fossil pollen data show that several different vegetation types, highland forests, woodland and grasslands, were available to the rich fauna and bipedal hominin Australopithecus afarensis. The local vegetation at Laetoli was woodland or wooded grassland, whereas highland forests were located on nearby volcanoes. The nine oldest Laetoli pollen spectra appear close in age to that recently obtained at Woranso/Mille, in the Lower Awash valley of the Ethiopian Rift (Saylor et al. 2019) at more than a thousand kilometres distance in the northern tropics. The occurrence of Acacia, Boscia, Celtis, Capparaceae, and several others at both sites despite strongly different sedimentological contexts, indicates a great expansion of this woodland vegetation that was widespread in the southern and northern tropics. Woodland and wooded grasslands close to forests were available both for A. anamensis in Ethiopia and A. afarensis in Tanzania. At Woranso-Mille, these hominins made use of mixed grassland-wooded vegetation more or less similar in composition to woodlands and grasslands existing in the Laetoli plains, 
but in Ethiopia such vegetation was associated with a more densely wooded riparian forest along an important river delta.

\subsection{MID-PLIOCENE (3.42-2.95 MA), ETHIOPIA}

Fossil pollen from this time period are only documented at Hadar site, $500 \mathrm{~m}$ asl, along the lower valley of the Awash River $\left(11^{\circ} 06^{\prime} \mathrm{N}, 40^{\circ} 35^{\prime} \mathrm{E}\right)$, in the Afar depression of the Ethiopian Rift (Figure 2). The sediments and intercalated volcanic tuffs were deposited in a low topography of a rapidly subsiding sedimentary basin (Roman et al. 2008). Pollen data from 27 samples (totalling over 15,000 counted grains) were obtained during the first years of palaeontological exploration of the research area (1973-1977). They were collected from sediments outcropping in the type sections of the Hadar Formation dated from 3.42 to $2.95 \mathrm{Ma}$ (Figure 5). In the original publication, these results were presented according to stratigraphic position and the conventional K-Ar dates available at that time (Bonnefille et al. 1987). We revisit here the chronological attribution of former pollen samples using the most recent tephro-chronostratigraphy, including additional ${ }^{40} \mathrm{Ar} /{ }^{39} \mathrm{Ar}$ dates and newly identified and dated tephra (tuffs) (Campisano 2007; Campisano and Feibel 2008a, 2008b; Roman et al. 2008) (Table 2, Figure 5).

The oldest pollen sample (398b) was collected at Oudaleita, a locality on the right bank of the Awash River (Bonnefille et al. 1987), now included in the research area of the Dikika Project, although the outcrops still belongs to the Hadar geological Formation. It was extracted from a lacustrine diatom-rich green clay intercalated between two layers of the Sidi Hakoma Tuff (SHT) that separates the Sidi Hakoma Member from the the Basal Member. SHT is precisely dated $3.42 \pm 0.03 \mathrm{Ma}$ at Hadar (Walter and Aronson 1993 revised by Campisano 2007) and correlates with two other tuffs from the Turkana basin (Brown 1982), notably with the Tulu Bor B at East Turkana also dated 3.42 $\pm 0.03 \mathrm{Ma}$ (McDougall et al. 2012). At the lowest level of the Sidi Hakoma Member of the Hadar Formation, the perfectly-dated pollen assemblage 398b shows a remarkable diversity of plants attested by 57 identified pollen taxa. This is partly explained by the high total pollen count (c. 1200 grains) providing highly reliable information. But such pollen assemblage fits well with deposition of fluvial deltaic channel, as shown by pollen content of a modern sample mud from the Awash River (Bonnefille 1969). Abundant grass pollen (36\%) are associated with Afroalpine herbs such as Alchemilla, Carduus, Laurembergia, Lythrum, Potamogeton and Hypericum, which today in Ethiopia is largely represented by an abundant small tree (rather than herb species) at the upper limit of the the forest zone. Therefore, such pollen assemblage likely documents mountain grassland above the forest zone, while sedges and Typha were scarce. A total of $24 \%$ pollen from trees and shrubs indicates an important tree cover, whereas the high pollen taxa diversity attests of extended well-established woodlands. Significant percentages of Celtis, Acacia, Dombeya, Ekebergia, Euclea, Brucea and Juniperus indicate that components of the present-day evergreen bushlands and deciduous woodlands that occupy the mid-elevation vegetation zone (1500-1800 m asl) on slopes of the northern Ethiopian plateau, were particularly dense at that time. A high percentage of ferns spores $(15 \%)$ in this oldest Hadar pollen sample is unusual and likely reflect high atmospheric humidity, or more humid conditions such as attested also by the occurrence of Alangium and Garcinia, these trees being components of more humid forests (Bonnefille et al. 1987).

The next samples $(\mathrm{n}=14)$ were collected within a 19 m-thick section exposed at Hurda wadi (previously spelled Ourda) and located c. $26 \mathrm{~m}$ above the SHT Tuff. This section of dark clay deposits includes a thick coal/lignite layer (sample KMe) intercalated between sandy levels of SH-2 and SH-3 sub-members. Recent geological study found that this lignite likely correlates to the thin darker unit layer within the new Kada Me'e Tuff complex (KMT), newly identified below the SH3 sands and dated 3.36 $\pm 0.02 \mathrm{Ma}$ (Campisano 2007; Campisano and Feibel 2008b). This date was not available in former publications, although it is in fairly good agreement with 
previous estimated chronological placement of the samples (Bonnefille et al. 2004, Figure 3). The chronology of the numerous pollen data from the lower SH-2 sub-member of the Sidi Hakoma Member is now well constrained. It spans a time interval of $c .30 \mathrm{kyr}$, from 3.38 to $3.35 \mathrm{Ma}$. Interpolated ages were calculated for sample KMa to m considering that all samples are located below the SH-3 sands. However, this unit defined in the Hadar type section is not clearly expressed in the Hurda section where clay deposits have a greater thickness than in the Hadar type sections (Campisano and Feibel 2008a). Pollen particularly well-preserved in the Hurda section are stratigraphically attributed to the SH-2 sub-member of the Hadar Formation. We attribute their preservation to anoxic conditions attested by the occurrence of Cyprideis ostracods indicating paludal environment (Peypouquet et al. 1983), and the presence of natrojarosite, a blue mineral attesting of acidic environment without clastic input (Tiercelin 1986).

The pollen assemblages are divided into two pollen zones showing different taxonomic composition and pollen percentages. The lower samples (KMa to i) surrounding the $3.36 \mathrm{Ma}$ lignite and KMT Tuff, are characterized by abundant pollen of grasses associated to sedges and aquatic Typha (23\% of the total pollen), a plant that requires freshwater. Typha pollen are recorded under such high percentages only in modern samples from periodically inundated delta setting, such as the Omo delta (Vincens 1982). Pollen of the aquatic Polygonum and abundant Asteraceae (former Compositae) confirm that it was similar to a high elevation swamp. The next five samples (KMj to m) show an important increase in arboreal pollen from humid forest such as Ilex, Myrica, Prunus and Hagenia, all trees characterizing the upper limit of the forest zone, such as in humid southwestern Ethiopian highlands (Bonnefille et al. 1993). These trees have low dispersal ability (Hamilton 1972). A total arboreal pollen percentage of $20 \%$, and the great number of tree taxa, many from mountain forests, a few from evergreen woodland, indicate that a diversified well-established humid forest occurred at a few kilometres distance from the Hurda section located closer to the depocenter of the Hadar lake. At that time, the landscape in this area was densely wooded with grasslands occupying the lake shores, with Typha and rare sedges swamp. Hominin remains have not been found at Hurda, but there are many of their fossils extracted from the Sidi Hakoma section in SH-2 and SH-3 sub-members of the Hadar area located a few kilometres west of Hurda. At Hadar, vertisol mudstones are representative of floodplain deposits of a meandering fluvial system in which remains of hominin fossils are found (Campisano and Feibel 2008a).

Following the chronological succession of the Hadar Formation, four pollen samples collected higher up in the stratigraphic section at localities 228, 280, 266 (Figure 2), in sediment yielding gastropod beds and pink marl below the Triple Tuff, are dated between $c .3 .30$ to $3.25 \mathrm{Ma}$ (Table 2). Although sediments deposited during this time period correspond to beach/nearshore and lacustrine environment (Campisano and Feibel 2008a), their pollen spectra strongly differ from those of the KM section (Bonnefille et al. 1987). Collected at sites all less than $5 \mathrm{~km}$ apart (Bonnefille et al. 1987), these pollen spectra show consistent results characterized by the predominance of grass pollen (c. 80\%), whereas Typha (5\%) and sedges $(10 \%)$ are recorded under much lower percentages. Pollen of mountain forest (0 to 5\%) disappear or occur as one or two taxa only. The herbaceous component of the pollen assemblages varies as expected in open grasslands with rare trees occupying the flat plains surrounding a large fluctuating lake. The occurrence of several herbs such as Alchemilla, Artemisia, Plantago, now common in the Afroalpine grassland, together with more abundant Asteraceae, associated with the dry conifer Juniperus, Phoenix (palm) tree, and Ericaceae shrubs indicates cooler conditions. At the top of the SH-4 sub-member included in the Mammoth event, drier, colder, and more variable climatic conditions were inferred by a statistical process used to calculate humidity coefficient from pollen data (Bonnefille et al. 2004). Sample $228 \mathrm{~b}$ collected at hominin locality 228 provided the lowest value of humidity coefficient.

Above in the stratigraphy, a group of six pollen samples was extracted from clay deposits in stratigraphic proximity to the Triple Tuff TT-4 initially dated at 3.26 Ma (Walter 1994), and 
now considered at $3.256 \pm 0.018 \mathrm{Ma}$ (Campisano 2007). Tuff TT-4 marks the limit between the Sidi Hakoma and the Denen Dora Members of the Hadar Formation. Abundance of grass pollen together with fluctuating percentages of the aquatic Typha and sedges, suggest vegetation typical of periodically flooded lake margins. The occurrence of the shrub Dodonaea viscosa observed as a pioneer on basaltic sub-modern lava flows (field observation by RB) and known as a fireresistant species, appears in sediment contemporaneous with eruption of the basalt. In these six samples, arboreal taxa such as Commiphora, Acacia, Hyphaene/Borassus, and Tamarix are pollen markers of the arid sub-desert steppe like the one now occupying the Rift Valley. The co-occurrences of these trees indicate that warmer climatic conditions established in the region c. $3.25 \mathrm{Ma}$, during a period of higher global climatic variability attested by the marine isotopic record (Dolan et al. 2015). At Hadar, in the lower Awash valley, samples dated $3.25 \mathrm{Ma}$ were collected at three distinct localities 134, 333 and 116, all found in the northern part of the Hadar area, upstream the Kada Hadar wadi (Bonnefille et al. 1987). A sample of green clay exposed at locality 134, below the TT-4 (top of SH-4 sub member) produced a total pollen count exceeding 2300 grains distributed among 34 distinct plant taxa. Grasses average $60 \%$ whereas tree pollen has increased with the addition of taxa commonly found in mid-elevation woodland such as Croton, Acacia, Dodonaea, Commiphora, Hyphaene/Borassus and Tamarix. All are indicators of woodland located at lower elevation, under warmer climatic conditions than mountain forest trees. Abundant pollen of herbs such as Amaranthaceae, Acanthaceae and Tribulus that grow on delta plains also indicate higher aridity and/or temperature or increased salinity of the lake waters and margins, a characteristic also indicated by ostracods assemblages from the same layer (Peypouquet et al. 1983).

The next three samples come from the hominin locality AL333, but are not contemporaneous with hominins remains since they were collected from sediment lower in the stratigraphy. A sample of sandy clay below TT-4 shows high grass percentage (66\%), associated with abundant Typha (32\%) suggesting the return of an extended marsh or a shallow freshwater fluctuating lake. Few tree pollen grains are found in the black clay that lies $50 \mathrm{~cm}$ below the ostracod layer. In the sample from the ostracod layer corresponding to the boundary between Sidi Hakoma and Denen Dora Members, grasses $(98 \%)$ dominate the pollen assemblage. We also note pollen from the aquatic herb of Onagraceae.

At locality 116 , two kilometres towards the escarpment, grass pollen is still dominant (82\%) and sedges increase. A subsequent percentage of olive tree pollen associated with Combretum and Euclea indicates that dry seasonal woodlands spread and came closer to the lake. The pollen sample 116e, upstream of the Kada Hadar wadi, may have consisted of a wooded grassland environment with olive trees on the northern slope towards the escarpment. In conclusion, the composition of pollen assemblages close in stratigraphy to the $3.25 \mathrm{Ma}$ dated Triple Tuff is in good agreement with lacustrine and episodic sub-aerial exposures of depositional environment at the top of the Sidi Hakoma Member, and the base of the Denen Dora Member (Campisano and Feibel 2008a).

After a gap in the record of c. 300 ka with no pollen information for the Kada Hadar Member, the next spectrum come from the brown clay exposed just below the ash fall Bouroukié Tuff (BKT-2), at locality $55 \mathrm{~N}$ where the first tuff sample was collected and provided the age of $2.88 \pm 0.08 \mathrm{Ma}$ (Walter and Aronson 1982). In the upper KH-2 sub-member, the BKT-2 Tuff complex is now considered 2.95 Ma (2.94-2.96 Ma by Campisano 2007; DiMaggio et al. 2008). A rich pollen assemblage $(n>1000)$ extracted from this clay shows more than 30 taxa and $7.5 \%$ trees and shrubs. The arboreal taxa are exclusively found in current Afromontane forests (Myrica, Podocarpus, Juniperus, Hagenia and Ericaceae) and others are markers of evergreen drier woodland/bushland (Euclea, Ekebergia, Dodonaea, Acacia and Rumex). Sedges, Typha and grasses constitute the herbaceous cover on shores of a shallow lake. A certain degree of salinity can be inferred from the high proportion of Amaranthaceae/Chenopodiaceae herbs or shrubs and the low proportion of Typha. 


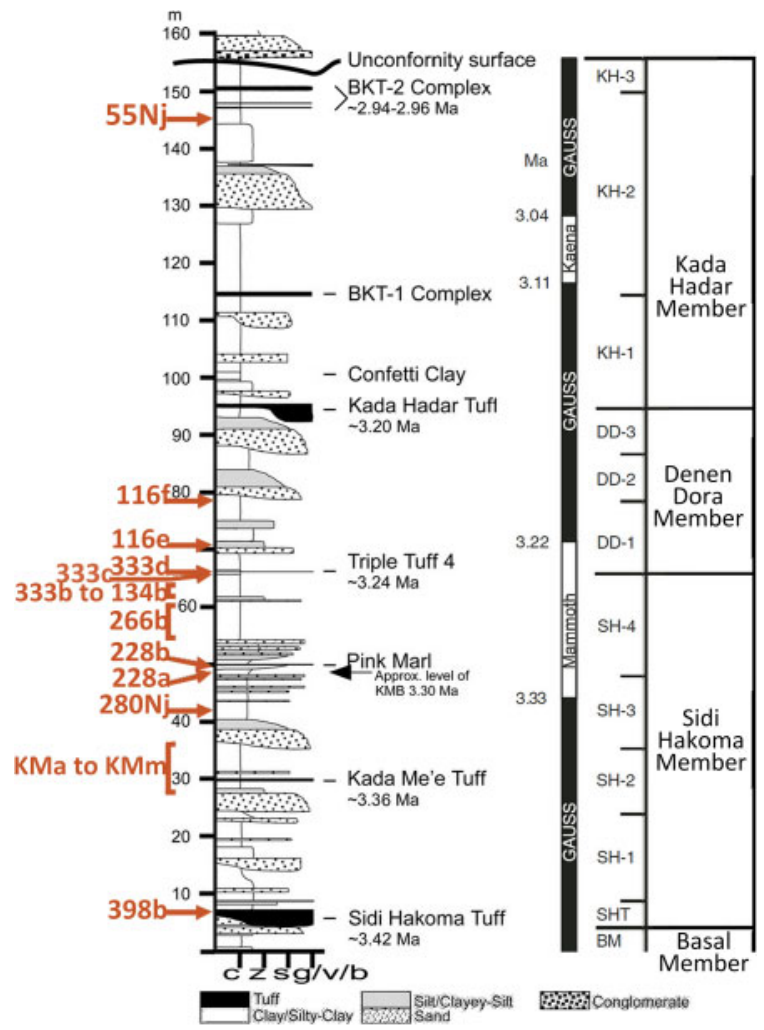

Figure 5. Stratigraphic position of the original pollen samples (red color) from Bonnefille et al., (1987), in the composite section of the Hadar Formation after Campisano and Feibel (2008).

After the deposition of BKT-2 Tuff, the Hadar geological Formation ends with a wellmarked unconformity (Figure 5). The Busidima Formation lies stratigraphically above it, after a gap of deposition of $c$. $0.3 \mathrm{Ma}$. Sediments of the Upper Pliocene (2.9 to 2.6 Ma) lack in the Hadar Formation. A few additional pollen spectra were extracted from archaeological horizons dated 2.35 Ma, i.e. in the Pleistocene Busidima Formation. They are not discussed in this paper restricted to the Pliocene.

\subsection{DISCUSSION}

\subsubsection{Interpretation of pollen data}

In the difficult challenge of interpreting pollen assemblages in terms of pattern of past vegetation, landscape or habitat we rely on our field experience and botanical knowledge of tropical vegetation improved by additional exploration of pollen signal from many other modern ecosystems in East Africa (Bonnefille 2011). In pollen studies from temperate vegetation where most pollen is dispersed by wind, taxa with the greatest percentages are assumed to reflect the local vegetation because the greatest amount of pollen is dispersed at proximity of the plant producing them. A similar pattern is suggested for tropical vegetation such as shown in the sub-desert vegetation 
of the plains surrounding lake Turkana (Bonnefille 1977). For example, pollen assemblages of modern soil samples collected in different vegetation zones along the slopes of the escarpment of the Ethiopian Rift, north of Hadar, provided pollen indicators of the distinct vegetation belts along an altitudinal gradient, the succession comprising samples from sub-desert steppe to evergreen bushland and Afromontane forest (Bonnefille et al. 1987). Different vegetation types illustrate a similar gradient on a broader scale in Tanzania (Vincens et al. 2006), whereas other samples from southwestern Ethiopia document humid forests from mountains (Bonnefille et al. 1993). However, in the tropical region, pollen from grasses, dispersed by wind, is produced in significantly greater amounts than pollen from other tropical plants, notably most forest trees (Hamilton 1982). As a consequence of this discrepancy, pollen percentages will not directly reflect the proportion of plants in one given vegetation type. Moreover, the sedimentological context in which the fossil pollen grains are deposited, modify the distribution pattern of the percentages of different taxa. Fluvial transport over long distances, can mix distinct pollen grains from various vegetation types, that do not necessarily reflect their surrounding ecological conditions (Vincens 1982). Composition of the pollen assemblage varies according to the deposition mode of the sediment. At Hadar, pollen assemblages such as from the mud of shallow fresh water lake or swamps are characterized by the abundance of Typha. Pollen assemblages such as sample 134 which is from a river channel deposit (Campisano and Feibel 2008a), includes a great diversity of pollen taxa from various vegetation types covering a larger source area, thus potentially representing the entire river basin (Bonnefille et al. 1987).

\subsubsection{Environment of hominins through the Mid and Upper Pliocene}

Through the million-year time span between 3.8 and 2.9 Ma, the 39 pollen assemblages discussed in this paper clearly indicate that geographically distinct hominin sites are associated with different types of vegetation. Grasslands, wooded grasslands, woodlands and forests (riparian or mountain), all existed, including different species composition and tree cover density. In a same region, pollen studies show that past vegetation types were also changing through time. In the lower Awash valley of Ethiopia, the oldest sample (4-3.8 Ma) from Meshellu now located at c. $500 \mathrm{~m}$ elevation, indicate proximity of high elevation mountain forest. At Worenso-Mille, the pollen assemblage associated to Australopithecus anamensis which fossil remains were found in the same strata dated to $3.8 \mathrm{Ma}$ at the same locality, documents a mid-elevation Acacia woodland with abundant Acacia, Cordia, Croton, Rhus, Tamarix and various shrub taxa from the Capparidaceae and also Amaranthaceae that indicate a warm climate. Closer to the northern Ethiopian escarpment, where deciduous and woodland dominated the local landscape some riparian forest and grasslands occupied the delta that also received a pollen signal of distal mountain forest. There are few highland dry conifer forests taxa such as Olea and Juniperus. A closely related mid-elevation woodland is documented at Laetoli in Tanzania, south of the equator, at about the time when the oldest $A$. afarensis appeared in the East African fossil record. Such drier past vegetation contrasts with that of more humid conditions found in the Lower Awash valley, a few hundred thousand years later when $A$. afarensis prevailed at Hadar.

It is at Hadar that well-preserved, numerous pollen data best document past vegetation. At Hadar from 3.4 to $3.2 \mathrm{Ma}$, the remarkable feature is the floristic affinities of the fossil taxa to components of the present Afromontane vegetation domain. These include taxonomic attribution of fossil pollen to living plants common in high elevation evergreen bushlands, forests and Afroalpine grasslands. These similarities clearly indicate much cooler and wetter vegetation and a past climate that contrasts sharply with the extremely arid current climate of the Afar region. During the Mid-Pliocene, atmospheric $\mathrm{CO}_{2}$ concentration was likely similar to today (400 ppm) (Ning Tan et al. 2020), which may partly explain forests expansion at that time. From $3.4 \mathrm{Ma}$ to 2.9 Ma, global decrease in $\mathrm{CO}_{2}$ concentration is postulated to have enhanced polar glaciation. During the Pliocene, oceanic and atmospheric circulations were totally different from the present 
situation. Some modelling experiments indicate more precipitation over East Africa at $3.3 \mathrm{Ma}$ (Dolan et al. 2015).

At 3.4 Ma, in the oldest deposits at Hadar, all the trees belong to woodlands and forests now encountered only in Ethiopian highlands (Friis et al. 2010). The fossil pollen data set lacks indicators of the common sub-desert trees (such as Capparidaceae, Salvadoraceae, Ziziphus, Combretaceae). Indeed, Mid-Pliocene vegetation at Hadar was markedly different from that of today. Australopithecus afarensis and A. anamensis were sharing a vegetated landscape that is difficult to reconstruct. Elevation and climatic conditions of the region differed markedly from the current palaeogeographical setting. In a subsiding flat spreading basin, the Hadar Lake could have been closer to the Rift escarpment and its relief. At that time, it could be postulated that the large lake was located at elevation much higher than $500 \mathrm{~m}$. Today forests are established above $1800 \mathrm{~m}$ elevation, under a minimum amount of over $1000 \mathrm{~mm} / \mathrm{yr}$ precipitation with no short dry season, and an average annual temperature of $18^{\circ} \mathrm{C}$. These requirements significantly contrast with the low rainfall, high temperature and long dry season of today's climatic conditions in the Rift. Regular characteristics of the sedimentology during the time interval 3.4 to $3.2 \mathrm{Ma}$, presume of stabilized forest soil and agree with pollen indicating forests occurrences. From 3.32 to $3.22 \mathrm{Ma}$, the climatically stable and humid lacustrine phase at Hada corresponds to a global period of low variability attested by the astronomically calculated lower insolation and precession amplitude (Campisano and Feibel 2007, Figure 3). In contrast, during the deposition of the KH-2 Member (3.12 to $2.96 \mathrm{Ma}$ ), drier conditions were inferred from faunal studies, notably the increase in bovid tribes (wildebeests and gazelles) adapted to grazing arid lands after $3.15 \mathrm{Ma}$ (Campisano and Reed 2007). The drying trend supported by faunal analysis cannot be confirmed by pollen since no data exist for this time range. DD and KH Members were not initially densely sampled for pollen studies. However, at the top of the KH-2 sub-member of the Hadar Formation, the pollen spectrum BK-2 documents open woodland indicating long dry seasons unsuitable for forest growth. Although derived from a single pollen assemblage, this interpretation is in good agreement with sedimentological and faunal interpretation of local environment and global climate patterns around $3 \mathrm{Ma}$.

\subsubsection{Pollen reconstructed climatic conditions}

An attempt to reconstruct climatic parameters from Hadar pollen data was performed (Bonnefille et al. 2004). Such method uses references of selected taxa frequencies in pollen assemblages obtained from 966 samples collected in different vegetation types at East African sites where corresponding meteorological parameters were interpolated. In 2001, R. Bonnefille collected at Hadar 13 new modern pollen assemblages from soil and river mud. Thirty years had passed since the collection of modern pollen data had been obtained and used as a calibration data set. We processed the new modern samples as if they were fossil ones and apply to them previous methodological approaches developed to calculate climatic parameters from upper Pleistocene and Holocene pollen data (Bonnefille et al. 1992; Jolly et al. 1998). The results could be compared to measured mean annual rainfall and temperature values provided by a meteorological station located nearby Hadar. Such procedure constituted a control test intended to validate our method. Indeed pollen-reconstructed values obtained for both modern surface soil and river samples collected in 2001 (these likely analogues to fossil pollen deposition) correspond closely to those measured at the nearby meteorological station (Bonnefille et al. 2004). Our statistical method was therefore validated. We could apply such likelihood procedure to infer mean annual precipitation and temperature for the Pliocene. Of course, the fact that climatic requirements from plant taxa during the Pliocene remained the same as today has to be an accepted assumption. For Hadar, the results indicate that from 3.42 to $3 \mathrm{Ma}$, mean annual terrestrial temperature was $c .10^{\circ} \mathrm{C}$ lower than the $25^{\circ} \mathrm{C}$ current value. Mean annual rainfall values average $1000 \mathrm{~mm} / \mathrm{yr}$, which is two to three times the amount registered today (Bonnefille et al. 2004). Moreover, a noticeable cold shift 
towards $15^{\circ} \mathrm{C}$ associated with a minor rainfall increase is registered at c. 3.36-3.35 Ma (samples KMk to KMm section, Figure 3, Table 2) after deposition of the anoxic black organic layer 'lignite' (KMe) dated by the KMT Tuff at $3.36 \pm 0.02 \mathrm{Ma}$ (Campisano 2007), and occurring in a stable deposition of lacustrine clay. Below the lower limit of the Mammoth sub-chron (3.33 Ma), the cool and humid event registered at Hadar appears in good contemporaneity with the oceanic first isotopic cooling event (Shackleton et al. 1995), therefore connecting a local environmental event to a global climatic event (Campisano and Feibel 2007). Pollen results and inferred climatic parameters clearly show that global climatic variations had a strong impact upon climate and vegetation in East Africa. However, the vegetation changes documented here for a few thousand years concern changing species of trees in the forest, but the forest was maintained in the region throughout this period. At Hadar, fossil remains of $A$. afarensis are found in many localities both before and after the cooling spell (below and above the SH-3 sands). The palaeo-geographical context indicates a permanent but fluctuating large lake, surrounded by periodically flooded flats covered by swampy sedges and cattail tall herbs. Located near a forest with great diversity of tree species, such environmental conditions offered various resources for food subsistence and shelter for this hominin which maintained abundant groups for more than half a million years.

Later, at about $2.95 \mathrm{Ma}$, when arctic glaciation extended, a single pollen assemblage documents past vegetation at Hadar. At that time a strong contrast was calculated in reconstructed values between mean annual temperature (MAT) inferred by 'best analogue' statistics and mean temperature of the coldest month (MTCO) inferred by the Plant Functional Type (PFT) method (Jolly et al. 1998). Mean annual precipitation remained high $(>1000 \mathrm{~mm})$, and the humidity coefficient showed its greatest value (Bonnefille et al. 2004). These values indicate stronger seasonal contrast in the local terrestrial climate, in good timing correspondence with increased variability of dust content registered in marine cores of the Arabian sea shown by a noticeable peak at 2.9 Ma (deMenocal 1995). In the marine core DSDP 231 from the Gulf of Aden, plant wax biomarkers show increased proportion of $\mathrm{C}_{4}$ plants, while pollen from the halophytes Chenopodiaceae/Amaranthaceae) are in greater percentages (Feakins et al. 2013) synchronously with the lowest percentages of total arboreal pollen (Bonnefille 2010). Several marine indicators point to strong changes over the whole East African region, and more contrasted climatic conditions at Hadar. However, in the Lower Awash Valley, trends towards more aridity did not reach a threshold that enabble forest growth from the Hadar region. Many species of forest and woodland trees (e.g. Olea, Podocarpus, Hagenia, Myrica, Macaranga, Acacia, Ekebergia, Nuxia, Euclea, Juniperus, Dodonaea) persisted in the basin, until $2.9 \mathrm{Ma}$, still offering food and shelter resources. The variety of tree species indicates a diversified forest that does not resemble riparian forests, impoverished in species such as those found nowadays in arid region along the Awash or the Omo Rivers. Riparian forests, although providing a locally wooded environment among arid grassland floodplains, are less diversified in trees and herbs species (Carr 1998) and they are geographically localized. They could not provide food and continuous long-term living conditions for early hominins populations such those found in the Lower Awash Valley for a million years. Composition of the riparian vegetation is known to change very quickly. However, when hominins seem to have disappeared from the region (at $2.9 \mathrm{Ma}$ ), greater seasonal temperature (and rainfall) contrasts possibly made living conditions more difficult than those experienced earlier by occupants in the Hadar/Dikika region.

During the middle Pliocene, from 3.8 to 3.2 Ma, multiple, roughly contemporaneous sites, all containing hominins, are present across East Africa, spanning regular occurrence of Australopithecus afarensis. At Hadar (Ethiopia), Laetoli (Tanzania), East and West Turkana (Kenya), hominins were rare members of large mammalian fossil communities. Significant discrepancies in hominin abundance versus other mammalian fossils could have been caused by local ecology rather than by taphonomic biases (Villaseñor et al. 2020). Indeed, at Hadar, local ecological conditions with diversified woodlands and forests, and local grasslands (strongly differing from 
modern savannah/steppe) provided favourable conditions for persistence of $A$. afarensis in the region. Stronger climatic changes after 2.9 Ma could have caused their extinction. But the Last Appearance Datum (LAD) of the species is difficult to determine due to a gap in the deposition of the sediments at Hadar after 2.9 Ma.

\subsection{CONCLUSIONS}

Pollen data from the Pliocene in East tropical Africa document many vegetation types that experienced strong changes in their taxonomic composition. Some of these changes occurred over a few thousand years. However, the resolution of the record is not sufficient to attribute them to fluctuations in precipitation following the monsoon precession cycle, although it is likely. Past vegetation for deposits $c .3 .8 \mathrm{Ma}$ is reconstructed as dense woodland or wooded grassland both in Tanzania south of the equator and Ethiopia, north of the equator. Such vegetation implies a seasonal distribution of rainfall over a broad region in East Africa. At 3.42 Ma many indicators of cool mountain forests and high elevation grasslands prevailed under humid conditions of higher rainfall, with short dry seasons that maintained forests at Hadar for more than 200 ka. A cold event documented slightly before $3.33 \mathrm{Ma}$, close to the lower limit of the Mammoth event, occurred in good timing connexion with the known marine isotope stage MIS M2 oceanic cooling and rainfall increase simulated by some model experiments (Dolan et al. 2015). At Hadar vegetation changes are indicated by modifications in the tree species composition of the forests. It is remarkable that such noticeable changes (both in vegetation and local climate) had no effect on $A$. afarensis local occurrences. Regarding hominins habitat, existing forests offered abundant and diverse food resources and shelters for $A$. afarensis. At Hadar, hominin fossils are found within sediments deposited before and after the cold spell. From 3.1 to $2.96 \mathrm{Ma}$, analyses of the fossil fauna, notably the abundance of different bovid tribes, are interpreted as indicating a drying trend in the palaeoenvironmental conditions. Increased body sizes of $A$. afarensis are documented synchronously. A single pollen assemblage confirms the drying trend post $2.9 \mathrm{Ma}$ at a time of greater variability of the global climate following increasing arctic glaciations.

\section{ACKNOWLEDGEMENTS}

We are grateful to two anonymous reviewers for their comments on an earlier version of the manuscript. We thank Doris Barboni for stimulating and encouraging this paper, her help to provide the data in digital format and final editing.

\section{REFERENCES}

Bamford, M.K., 2011, Fossil Leaves, Fruits and Seeds, In: Harrison, T. (Ed.), Paleontology and Geology of Laetoli: Human Evolution in Context: Volume 1: Geology, Geochronology, Paleoecology and Paleoenvironment, Vertebrate Paleobiology and Paleoanthropology Series. (Springer: Netherlands, Dordrecht), pp. 235-252, 10.1007/978-90-481-9956-3_11.

Barboni, D., Ashley, G.M., Bourel, B., Arráiz, H., Mazur, J.-C., 2019, Springs, palm groves, and the record of early hominins in Africa. Review Palaeobotany Palynology 266, pp. 23-41, 10.1016/j.revpalbo.2019.03.004.

Bonnefille, R., 1969, Analyse pollinique d'un sediment recent: vases actuelles de la riviere Aouache (Ethiopie). Pollen et Spores, 11, pp. 7-16.

Bonnefille, R., 1971a, Atlas des pollens d'Ethiopie: Pollens actuels de la basse vallee de l'omo, recoltes botaniques 1968. Adansonia, 2, pp. 463-518. 
Bonnefille, R., 1971b, Atlas des pollens d'Éthiopie: Principales espéces des forêts de montagne. Pollen et Spores, 13, pp. 15-72.

Bonnefille, R., 1977, Représentation pollinique d'environnements arides à l'Est du Lac Turkana (Kenya). Presented at the $9^{\circ}$ Congrès INQUA, Bulletin de l'Association française pour l'étude du quaternaire, Birmingham, UK, pp. 235-247.

Bonnefille, R., 2010, Cenozoic vegetation, climate changes and hominid evolution in tropical Africa. Global Planetary Change, 72, pp. 390-411, 10.1016/j.gloplacha.2010.01.015.

Bonnefille, R., 2011, Rainforest responses to past climatic changes in tropical Africa, in: Bush, M., Flenley, J., Gosling, W. (Eds.), Tropical Rainforest Responses to Climatic Change, Springer Praxis Books. Springer, Berlin, Heidelberg, pp. 125-184, 10.1007/978-3-64205383-2_5.

Bonnefille, R., and Riollet, G., 1980, Pollens des savanes d'Afrique orientale. Centre national de la recherche scientifique, Paris, France.

Bonnefille, Vincens, A., and Buchet, 1987, Palynology, stratigraphy and palaeoenvironment of a pliocene hominid site (2.9-3.3 M.Y.) at Hadar, Ethiopia. Palaeogeography Palaeoclimatology Palaeoecology, 60, pp. 249-281, 10.1016/0031-0182(87)90035-6.

Bonnefille, R., Riollet, G., 1987, Palynological spectra from the Upper Laetolil Beds, in: The Pliocene Site of Laetoli, Northern Tanzania. Leakey, M.D., Harris, J.M. (Eds.), Oxford, pp. 52-61.

Bonnefille, R., Buchet, G., Friis, I.B., Kelbessa, E., Mohammed, M.U., 1993, Modern pollen rain on an altitudinal range of forests and woodlands in South West Ethiopia. Opera Botanica 121, pp. 71-84.

Bonnefille, R., Chalié, F., Guiot, J., Vincens, A., 1992, Quantitative estimates of full glacial temperatures in equatorial Africa from palynological data. Climate Dynamics 6, pp. 251-257, 10.1007/BF00193538.

Bonnefille, R., Potts, R., Chalié, F., Jolly, D., Peyron, O., 2004, High-resolution vegetation and climate change associated with Pliocene Australopithecus afarensis. Proceedings of the National Academy of Sciences, 101, pp. 12125-12129, 10.1073/pnas.0401709101.

Bourel, B., 2020, Pollen use for the spatial high-resolution reconstruction of Plio-Pleistocene Hominini environments in the East African Rift (Ethiopia and Tanzania). Aix-Marseille Université, Aix-en-Provence, France.

Brown, F.H., 1982, Tulu Bor tuff at Koobi Fora correlated with the Sidi Hakoma tuff at Hadar. Nature, 300, pp. 631-633, 10.1038/300631a0.

Campisano, C.J., 2007, Tephrostratigraphy and hominin paleoenvironments of the Hadar Formation, Afar Depression, Ethiopia. Rutgers University - Graduate School-New Brunswick. https://doi.org/10.7282/T3NS0V99

Campisano, C.J., 2012, Geological summary of the Busidima Formation (Plio-Pleistocene) at the Hadar paleoanthropological site, Afar Depression, Ethiopia. Journal of Human Evolution 62, pp. 338-352, 10.1016/j.jhevol.2011.05.002

Campisano, C.J. and Feibel, C.S., 2007, Connecting local environmental sequences to global climate patterns: evidence from the hominin-bearing Hadar Formation, Ethiopia. Journal of Human Evolution, African Paleoclimate and Human Evolution 53, pp. 515-527. 10.1016/j.jhevol.2007. 05.015 .

Campisano, C.J., and Reed, K.E., 2007, Spatial and temporal patterns ofAustral-opithecus afarensishabitats at Hadar, Ethiopia, in: Abstracts. Presented at the Paleoanthropology SocietyAnnual Meeting, Philadelphia, Pennsylvania, p. A6.

Campisano, C.J., Feibel, C.S., 2008a, Depositional environments and stratigraphic summary of the Pliocene Hadar Formation at Hadar, Afar Depression, Ethiopia, Geological Society of America Special Papers, 446, pp. 179-2011. 
Campisano, C.J., Feibel, C.S., 2008b, Tephrostratigraphy of the Hadar and Busidima Formations at Hadar, Afar Depression, Ethiopia, in: The Geology of Early Humans in the Horn of Africa. Geological Society of America, pp. 135-162.

Campisano, C.J., Cohen, A.S., Arrowsmith, J.R., Asrat, A., Behrensmeyer, A.K., Brown, E.T., Deino, A.L., Deocampo, D.M., Feibel, C.S., Kingston, J.D., Lamb, H.F., Lowenstein, T., Noren, A., Olago, D., Owen, R.B., Pelletier, J.D., Potts, R., Reed, K.E., Renaut, R.W., Russell, J.M., Russell, J.L., Schäbitz, F., Trauth, M.H., Wynn, J.G., 2017, The Hominin Sites and Paleolakes Drilling Project: High-resolution paleoclimate records from the East African Rift System and their implications for understanding the environmental context of hominin evolution. Paleo Anthropology, 2017, pp. 1-43, 10.1130/abs/2017am-295426.

Carr, C.J., 1998, Patterns of vegetation along the Omo River in southwest Ethiopia. Plant Ecolology, 135, pp. 135-163. 10.1023/A:1009704427916.

Cohen, A., Campisano, C., Arrowsmith, R., Asrat, A., Behrensmeyer, A.K., Deino, A., Feibel, C., Hill, A., Johnson, R., Kingston, J., Lamb, H., Lowenstein, T., Noren, A., Olago, D., Owen, R.B., Potts, R., Reed, K., Renaut, R., Schäbitz, F., Tiercelin, J.-J., Trauth, M.H., Wynn, J., Ivory, S., Brady, K., O’Grady, R., Rodysill, J., Githiri, J., Russell, J., Foerster, V., Dommain, R., Rucina, S., Deocampo, D., Russell, J., Billingsley, A., Beck, C., Dorenbeck, G., Dullo, L., Feary, D., Garello, D., Gromig, R., Johnson, T., Junginger, A., Karanja, M., Kimburi, E., Mbuthia, A., McCartney, T., McNulty, E., Muiruri, V., Nambiro, E., Negash, E.W., Njagi, D., Wilson, J.N., Rabideaux, N., Raub, T., Sier, M.J., Smith, P., Urban, J., Warren, M., Yadeta, M., Yost, C., Zinaye, B., 2016. The Hominin Sites and Paleolakes Drilling Project: inferring the environmental context of human evolution from eastern African rift lake deposits. Scientific Drilling 21, pp. 1-16, 10.5194/sd-21-1-2016.

Deino, A.L., 2011, 40 Ar/39 Ar dating of Laetoli, Tanzania, in: Paleontology and Geology of Laetoli: Human Evolution in Context. Springer, pp. 77-97.

Deino, A.L., 2011, 40Ar/39Ar Dating of Laetoli, Tanzania, in: Harrison, T. (Ed.), Paleontology and Geology of Laetoli: Human Evolution in Context. Volume 1: Geology, Geochronology, Paleoecology and Paleoenvironment, Vertebrate Paleobiology and Paleoanthropology. (Springer Science+Business Media B.V.: Netherlands), pp. 77-97.

deMenocal, P., 1995, Plio-Pleistocene African Climate. Science, 270, pp. 53-59, 10.1126/science.270.5233.53.

DiMaggio, E.N., Campisano, C.J., Arrowsmith, J.R., Reed, K.E., Swisher, C.C., Lockwood, C.A., 2008, Correlation and stratigraphy of the BKT-2 volcanic complex in west-central Afar, Ethiopia, in: The Geology of Early Humans in the Horn of Africa. Geological Society of America. 10.1130/2008.2446(07).

Dolan, A.M., Haywood, A.M., Hunter, S.J., Tindall, J.C., Dowsett, H.J., Hill, D.J., Pickering, S.J., 2015. Modelling the enigmatic late pliocene glacial event-Marine isotope stage $\mathrm{m} 2$. Global Planetary Change, 128, pp. 47-60, 10.1016/j.gloplacha.2015.02.001.

Erbello, A., Kidane, T., 2018, Timing of volcanism and initiation of rifting in the Omo-Turkana depression, southwest Ethiopia: Evidence from paleomagnetism. Journal of African Earth Sciences 139, pp. 319-329, 10.1016/j.jafrearsci.2017.12.031.

Feakins, S.J., Levin, N.E., Liddy, H.M., Sieracki, A., Eglinton, T.I., Bonnefille, R., 2013, Northeast African vegetation change over 12 m.y. Geology, 41 G33845.1. 10.1130/G33845.1.

Friis, I., Demissew, S., van Breugel, P., 2010, Atlas of the potential vegetation of Ethiopia, The Royal Danish Academy of Sciences and Letters. ed. Det Kongelige Danske Videnskabernes Selskab, Copenhagen.

Garello, D.I., 2019, Tephrostratigraphy of Pliocene Drill Cores from Kenya and Ethiopia, and Pleistocene Exposures in the Ledi-Geraru Research Project Area, Ethiopia: Geological Context for the Evolution of Australopithecus and Homo (Ph.D.). Ann Arbor, United States.

Hamilton, A.C., 1972, The interpretation of pollen diagrams from highland Uganda. Palaeoecology of Africa, 7, pp. 45-149. 
Hamilton, A.C., 1982, Environmental history of East Africa: A study of the Quaternary. Academic press London.

Harrison, T., 2011, Laetoli Revisited: Renewed Paleontological and Geological Investigations at Localities on the Eyasi Plateau in Northern Tanzania, in: Harrison, T. (Ed.), Paleontology and Geology of Laetoli: Human Evolution in Context: Volume 1: Geology, Geochronology, Paleoecology and Paleoenvironment, Vertebrate Paleobiology and Paleoanthropology Series. (Springer: Netherlands, Dordrecht), pp. 1-15. 10.1007/978-90-481-9956-3_1.

Hay, R., 1987, Geology of the Laetoli area, in: Laetoli: A Pliocene Site in NorthernTanzania. Oxford, United Kingdom, pp. 23-47.

Jolly, D., Prentice, I.C., Bonnefille, R., Ballouche, A., Bengo, M., Brenac, P., Buchet, G., Burney, D., Cazet, J.-P., Cheddadi, R., 1998, Biome reconstruction from pollen and plant macrofossil data for Africa and the Arabian peninsula at 0 and 6000 years. Journal of Biogeography. 25, pp. 1007-1027, 10.1046/j.1365-2699.1998.00238.x.

Jolly-Saad, M.-C., Bonnefille, R., 2012, Lower Pliocene Fossil Wood from the Middle Awash Valley, Ethiopia. Palaeontographica Abt. B 43-73, 10.1127/palb/289/2012/43.

Jolly-Saad, M.-C., Dupéron-Laudoueneix, M., Dupéron, J., Bonnefille, R., 2010, Ficoxylon sp., a fossil wood of 4.4 Ma (Middle Awash, Ethiopia). Comptes Rendus Palevol 9, pp. 1-4, 10.1016/j.crpv.2009.12.001.

Leakey, M.D. Mary D., Harris, J.M., 1987, Laetoli, A Pliocene site in northern Tanzania, (Oxford University Press: Oxford, United Kingdom).

Lisiecki, L.E., Raymo, M.E., 2005, A Pliocene-Pleistocene stack of 57 globally distributed benthic $\delta^{18}$ O records. Paleoceanography 20, 10.1029/2004PA001071.

McDougall, I., Brown, F.H., Vasconcelos, P.M., Cohen, B.E., Thiede, D.S., Buchanan, M.J., 2012, New single crystal 40Ar/39Ar ages improve time scale for deposition of the Omo Group, Omo-Turkana Basin, East Africa. Journal of the Geological Society, 169, pp. 213-226, 10.1144/0016-76492010-188.

Peypouquet, J.P., Carbonel, P., Taieb, M., Tiercelin, J.J., Perinet, G., 1983, Ostracoda and evolution process of paleohydrologic environments in the Hadar Formation (the Afar Depression, Ethiopia). in Maddocks, R.F., ed., Applications of Ostracoda: Houston, Texas, University of Houston Geosciences, pp. 277-285.

Reynolds, S.C., Bailey, G.N., King, G.C.P., 2011, Landscapes and their relation to hominin habitats: Case studies from Australopithecus sites in eastern and southern Africa. Journal of Human Evalution 60, pp. 281-298, 10.1016/j.jhevol.2010.10.001.

Roman, D.C., Campisano, C.J., Quade, J., DiMaggio, E.N., Arrowsmith, J.R., Feibel, C., 2008, Composite tephrostratigraphy of the Dikika, Gona, Hadar, and Ledi-Geraru project areas, northern Awash, Ethiopia, in: The Geology of Early Humans in the Horn of Africa. (Geological Society of America: Boulder, Colorado), pp. 119-134.

Rossouw, L. and Scott, L., 2011, Phytoliths and pollen, the microscopic plant remains in Pliocene volcanic sediments around Laetoli, Tanzania, in: Harrison, T. (Ed.), Paleontology and Geology of Laetoli: Human Evolution in Context. Volume 1: Geology, Geochronology, Paleoecology and Paleoenvironment. (Springer Science+Business Media B.V.: Dordrecht).

Saylor, B.Z., Gibert, L., Deino, A., Alene, M., Levin, N.E., Melillo, S.M., Peaple, M.D., Feakins, S.J., Bourel, B., Barboni, D., 2019, Age and context of mid-Pliocene hominin cranium from Woranso-Mille, Ethiopia. Nature, 573, pp. 220-224, 10.1038/s41586-019-1514-7.

Tiercelin, J.J., 1986, The Pliocene Hadar Formation, Afar depression of Ethiopia. Geological Society of London Special Publication, 25, pp. 221-240, 10.1144/GSL.SP.1986.025.01.19.

van Breugel, P., Breugel, P. van, Kindt, R., Lillesø, J.-P.B., Bingham, M., Demissew, S., Dudley, C., Friis, I., Gachathi, F., Kalema, J., Mbago, F.M., Moshi, H.N., Mulumba, J., Namaganda, M., Ndangalasi, H.J., Ruffo, C.K., Védaste, M., Jamnadass, R., Graudal, L., 2015, Potential Natural Vegetation Map of Eastern Africa (Burundi, Ethiopia, Kenya, Malawi, Rwanda, Tanzania, Uganda and Zambia). Version 2.0. https;//vegetationmap4africa.org. 
Villaseñor, A., Bobe, R., Behrensmeyer, A.K., 2020, Middle Pliocene hominin distribution patterns in Eastern Africa. Journal of Human Evolution, 147, 102856. 10.1016/j.jhevol. 2020.102856.

Vincens, A., 1982, Palynologie, environnements actuels et plio-pléistocènes l'Est du Lac Turkana (Kenya). PhD thesis, University Aix-Marseille II, Marseille, France.

Vincens, A., Bremond, L., Brewer, S., Buchet, G., Dussouillez, P., 2006, Modern pollen-based biome reconstructions in East Africa expanded to southern Tanzania. Review of Palaeobotany and Palynology, 140, pp. 187-212, 10.1016/j.revpalbo.2006.04.003.

Walter, R.C., Aronson, J.L., 1993, Age and source of the Sidi Hakoma tuff, Hadar formation, Ethiopia. Journal of Human Evolution, 25, pp. 229-240, 10.1006/jhev.1993.1046.

White, F., 1983, The vegetation of Africa., Courvoisier S.A. ed. Unesco, Paris, France.

White, T.D., Asfaw, B., Beyene, Y., Haile-Selassie, Y., Lovejoy, C.O., Suwa, G., WoldeGabriel, G., 2009, Ardipithecus ramidus and the Paleobiology of Early Hominids. Science, 326, pp. 64-64, 75-86, 10.1126/science. 1175802

WoldeGabriel, G., Ambrose, S.H., Barboni, D., Bonnefille, R., Bremond, L., Currie, B., DeGusta, D., Hart, W.K., Murray, A.M., Renne, P.R., 2009, The geological, isotopic, botanical, invertebrate, and lower vertebrate surroundings of Ardipithecus ramidus. Science, 326, pp. 65-65e5, 10.1126/science. 1175817 .

Wynn, J.G., Alemseged, Z., Bobe, R., Geraads, D., Reed, D., Roman, D.C., 2006, Geological and palaeontological context of a Pliocene juvenile hominin at Dikika, Ethiopia. Nature, 443, pp. 332-336, 10.1038/nature05048 


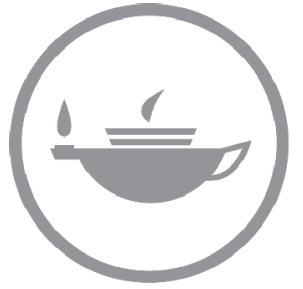

Taylor \& Francis Taylor \& Francis Group http://taylorandfrancis.com 